\title{
The Morphology of the Subtropical Anticyclone
}

\author{
By Y. Neyama \\ Hiroshima District Meteorological Observatory, Hiroshima \\ (Manuscript received 7 February 1968, in revised form 30 August 1968)
}

\begin{abstract}
In order to study the morphology of the subtropical anticyclone, the monthly mean patterns in August were analyzed in the layers from the troposphere up to the lower stratosphere. From the thickness distribution along $30^{\circ} \mathrm{N}$ at upper isobaric levels, it is seen that in the layers above $500 \mathrm{mb}$ level the southern Asia anticyclone shows a higher temperature than in the northwestern Pacific anticyclone. Also it is observed that the anticyclone over the North American Continent shows a lower temperature than the southern Asia anticyclone. The temperature field in the Atlantic anticyclone is not clear. The difference of temperature between the two anticyclones over the Asiatic and North American Continents may be attributable to the different thermal influence of the Himalays and the Rockies, because the temperature distribution may greatly depend on the shape of the large scale mountain. The development (decay) of the northwestern Pacific anticyclone on the $500 \mathrm{mb}$ level corresponds to weakening (intensification) of the polar low. However, the strength of the southern Asia anticyclone on the $100 \mathrm{mb}$ level is not related to that of either polar low at the same level or the northwestern Pacific anticyclone at lower levels. Therefore we cannot consider that the northwestern Pacific anticyclone at the surface level is linked vertically with the southern Asia anticyclone.* It is speculated that the axis of the northwestern Pacific anticyclone tilts westward with altitude and connects with a separate anticyclone or an anticyclonic cell appearing off the east coast of the Continent of Eurasia. Also the Atlantic anticyclone at the surface level does not connect with the North American anticyclone on the $100 \mathrm{mb}$ level. The northwestern Pacific anticyclone and the Atlantic anticyclone predominate in lower layers than in the mid-troposphere, but they are different in intensity. The southern Asia anticyclone becomes stronger than the North American anticyclone in the layers between the $300 \mathrm{mb}$ and $100 \mathrm{mb}$ levels.
\end{abstract}

\section{Introduction}

In the middle latitudes in the Northern Hemisphere, anticyclones are observed on the surface level in summer with the center over the North Pacific Ocean and the Atlantic Ocean (Fig. 1). The anticyclonic cell, which appears over the north western part of the Pacific Ocean on the daily surface map, is particularly called the Ogasawara anticyclone in Japan. On the $200 \mathrm{mb}$ and $100 \mathrm{mb}$ levels (Figs. 2 and 3), there are two anticyclones, one over the Tibetan Plateau and the other over the North American Continent. Both the anticyclones develop remarkably in

* The southern Asia anticyclone is called the Tibetan anticyclone or the upper tropospheric monsoonal anticyclone in the Indian literature, and the anticyclone over southern Asia or the south Asian anticyclone in the papers in America and China.

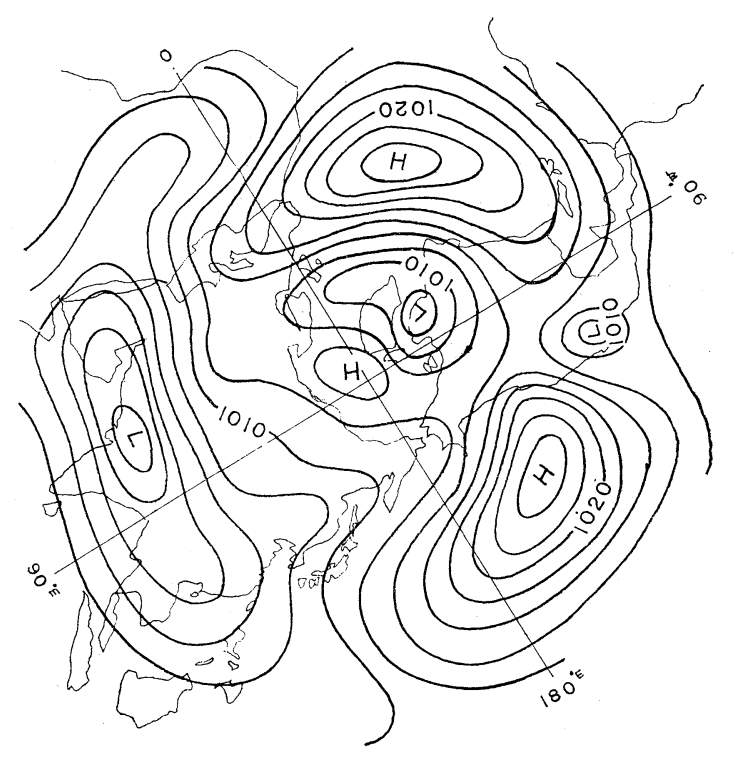

Fig. 1. Surface normal chart in August. 


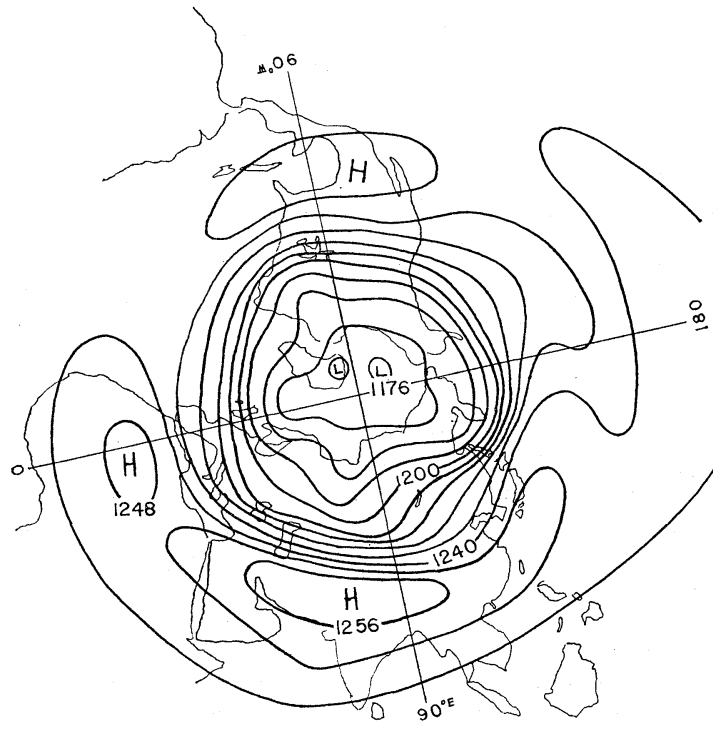

Fig. 2. Monthly mean $200 \mathrm{mb}$ chart in 1964 . August, after Free University of Berlin.

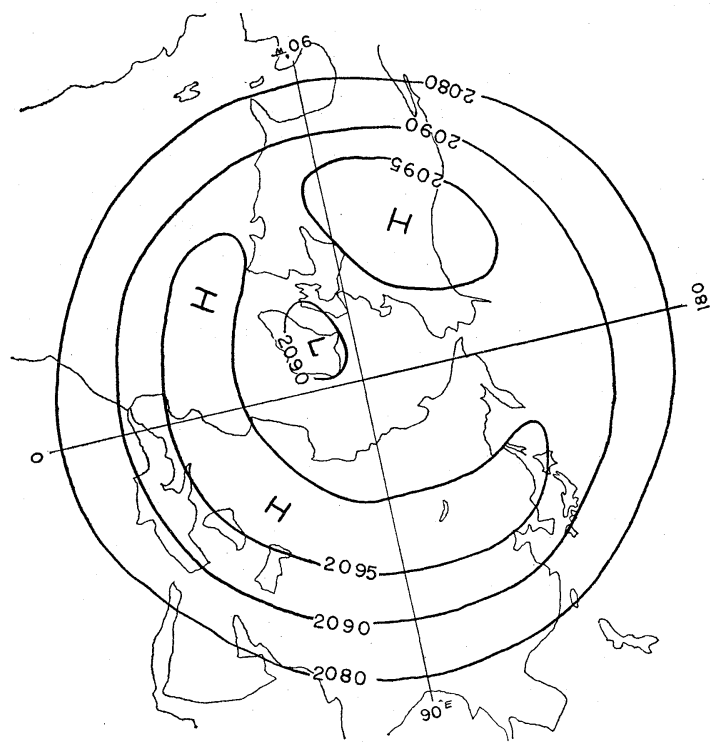

Fig. 4. $50 \mathrm{mb}$ normal chart in August, after Free University of Berlin.

summer. On the $50 \mathrm{mb}$ level, the anticyclones are still located over both continents, but their positions are shifted toward higher latitudes north of $30^{\circ} \mathrm{N}$, and they are ill-defined in intensities than those on the $100 \mathrm{mb}$ level (Fig. 4). Above the $25 \mathrm{mb}$ level (Fig. 5), no middle latitiudes anticyclone is noticed any longer and there prevails in the subtropics the circumpolar easterly current in parallel with the latitudinal circle.

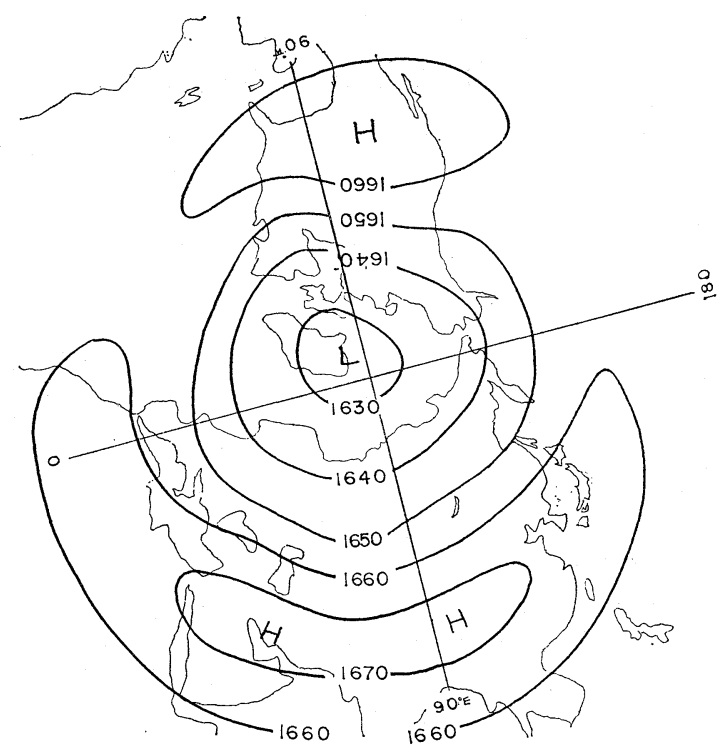

Fig. 3. $100 \mathrm{mb}$ normal chart in August, after Free University of Berlin.

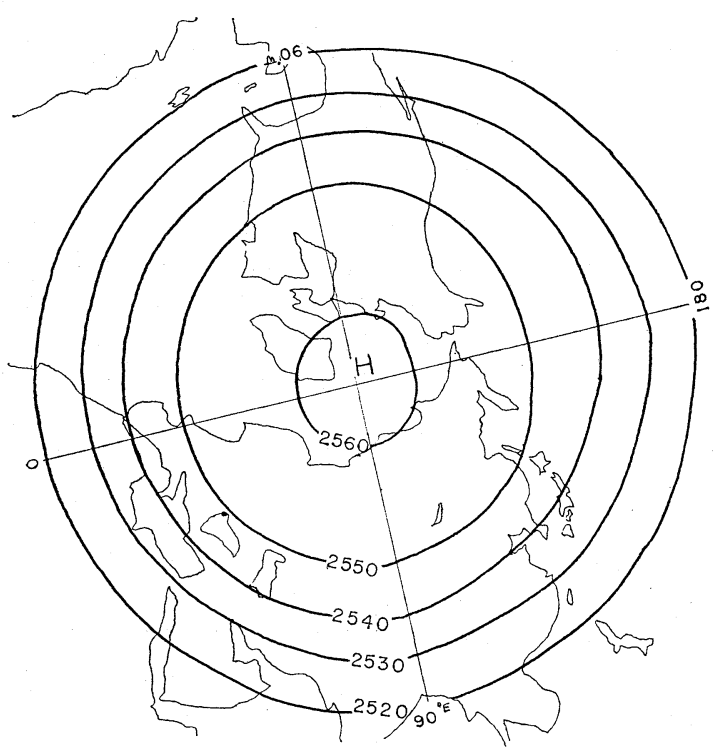

Fig. 5. $25 \mathrm{mb}$ normal chart in August, after Free University of Berlin.

When the southern Asia anticyclone on the 100 $\mathrm{mb}$ level leaves the Tibetan Plateau and a new anticyclone is formed near $110^{\circ} \mathrm{E} .30^{\circ} \mathrm{N}$, the northwestern Pacific anticyclone at the surface level marches toward northwest and reaches the Continent of Eurasia. On the other hand, when the separate anticyclone comes back to the Plateau, the northwestern Pacific anticyclone moves southeastward leaving the Asian Continent 
(Dao and Chu, 1965). The present author revealed that, when the closed anticyclonic contour line on the $100 \mathrm{mb}$ chart firstly appeared in April over the Pacific Ocean far to the south of Japan, the Ogasawara anticyclone became stronger than normal in the following August; when the anticyclone firstly formed over the South China Sea in April, the Ogasawara anticyclone became weak in summer (Neyama, 1965). He also found that a remarkable sudden increase in the zonal index on the $10 \mathrm{mb}$ level was observed about a month prior to the rapid development of the northwestern Pacific anticyclone on the $500 \mathrm{mb}$ level. In other words the conspicuous intensification of the easterly jet stream in the midstratosphere in the low latitudes may be used as a predictor of the summer anticyclone near Japan (Neyama, 1966). Further, it was shown that the decay of the Ogasawara anticyclone at the end of the summer season took place about five 5-day periods later than the date of disappearance of the polar anticyclone surrounded by $31760 \mathrm{gpm}$ contour line on the $10 \mathrm{mb}$ chart (Neyama, 1967).

In the present paper, the vertical structure of the subtropical anticyclone in summer throughout the troposphere and the stratosphere is studied mainly on the basis of the monthly mean maps and data. The materials used here are the 30, 50 , and $100 \mathrm{mb}$ maps issued by Free University of Berlin and the monthly climatic data and daily data over the world issued by the U.S. Weather Bureau.

\section{The state of the subtropical anticyclone at the surface level}

Table 1 shows the signs of the monthly mean surface pressure anomalies in the subtropical anticyclone and monthly mean temperature anomalies on the Japan Islands in nine August of 1957-65. From this table, it is seen that in some cases both the Pacific and the Atlantic anticyclone are stronger than normal while in others the pressure anomalies of both anticyclones show the opposite signs. The same facts are also grasped in the relationship between the western cell and the eastern cell in the northwestern Pacific anticyclone.

On the monthly mean pressure anomalies distribution mentioned above, it is comprehended that, at the surface level, the subtropical anticyclones in the Pacific and the Atlantic Ocean do not always show the same sign of pressure anomaly in the same year. Both the Pacific anticyclone and the Atlantic anticyclone show negative anomalies in 1957, 1959 and 1964, and positive anomalies in 1960, 1962 and 1963.

It is told among Japanese forecasters that the summer in Japan is hot when the northwestern Pacific anticyclone is strong. However, in August 1958 when the northwestern Pacific anticyclone was stronger than normal, the surface temperature on the Japan proper was below normal. The anticyclone in 1964 was weaker, but the abovenormal temperature was observed on the Eastern

Table 1. The deviation of surface pressure and temperature from the normal values in August from 1957 through 1965.

\begin{tabular}{r|r|r|r|r|r|r}
\hline & \multicolumn{3}{|c|}{$\begin{array}{c}\text { Deviation of monthly mean surface } \\
\text { pressure from the normal }\end{array}$} & \multicolumn{3}{c}{$\begin{array}{c}\text { Deviation of monthly mean surface } \\
\text { temperature from the normal }\end{array}$} \\
\cline { 3 - 7 } Year & Western Pacific & Eastern Pacific & Atlantic Ocean & Hokkaido & East Japan & West Japan \\
\hline 1957 & - & - & - & - & + & + \\
58 & + & - & - & - & - & - \\
59 & - & - & - & - & - & 0 \\
60 & + & + & + & + & + & + \\
61 & + & - & - & + & + & + \\
62 & + & + & + & - & + & + \\
63 & + & - & + & + & + & + \\
64 & - & + & - & - & + & + \\
65 & + & - & - & - & + & + \\
\hline
\end{tabular}


and Western Japan. These facts suggest that the climate of Japan in summer is not determined exclusively by the strength of the Pacific anticyclone.

\section{The vertical distributions and the characteristics of the subtropical anticyclone}

The vertical structure of the subtropical anticyclone in August 1959 and 1960 is analyzed by using the zonal cross-section of the isobaric height field along $30^{\circ} \mathrm{N}$ latitude. Figs. $6 \mathrm{~A}$ and $\mathrm{B}$ indicate the monthly mean height distribution along $30^{\circ} \mathrm{N}$ in August 1959 and 1960 at each level of the surface, $850,700,500,300,200,150$ and $100 \mathrm{mbs}$. The areas surrounded by (—) in the figures show the longitudinal width keeping a certain height, the standard height indicating the anticyclonic area on the normal chart, at each level. From these figures, it is clearly seen that in both years a distinct anticyclone is in existence between the $300 \mathrm{mb}$ and the $100 \mathrm{mb}$ level over the Tibetan Plateau and another one over the sea to the east off the Continent of Eurasia while no anticyclone is observed in this height interval over the North American Continent. The extension in east-west direction of the anticyclonic area is nearly similar at each of $300,200,150$ and $100 \mathrm{mbs}$ levels over the Tibetan Plateau in both years. In 1959, there is no area of surface pressure higher than $1020 \mathrm{mb}$ on both oceans, but areas of high pressure over $1020 \mathrm{mb}$ appear in 1960 . Moreover, the anticyclonic area (the shaded part in Fig. 6) with an isobaric height over a certain height is seen at layers between $850 \mathrm{mb}$ and $500 \mathrm{mb}$ level over both oceans in 1960, but it is not observed in the year of 1959. If the northwestern Pacific anticyclone at the surface level has an axis tilting toward west, it will couple with a separate anticyclone or anticyclonic cell which appears at the sea level to the east of Eurasian Continent and extends vertically to the levels above $300 \mathrm{mb}$, and the angle of inclination between the surface and the $100 \mathrm{mb}$ level is about 80 degrees. The axis of Atlantic anticyclone has scarcely any tilt. To confirm the existence of the separate anticyclone, the positions of anticyclone center on the $100 \mathrm{mb}$ daily charts are plotted in Fig. 7 in 1964 and 1965. From this figure, it is clearly seen that the positions of frequent occurrence of anticyclone center concentrate over the southern Asia and in the vicinity of Japan. The area of

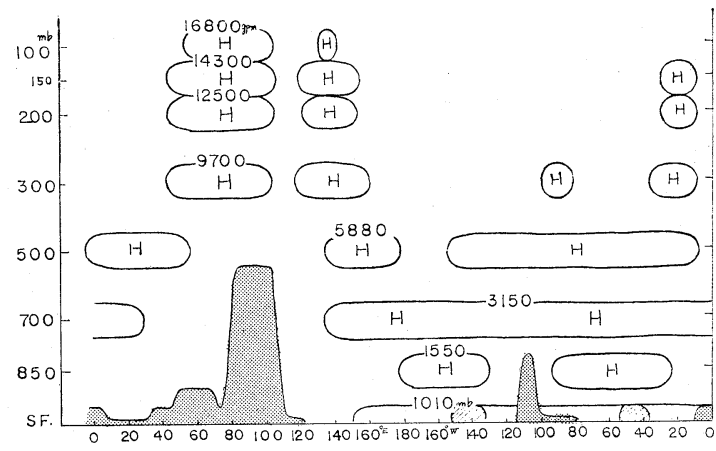

Fig. 6 A. Zonal cross section of the height field along $30^{\circ} \mathrm{N}$ latitude in August 1960. The area surrounded by (- indicates zonal width of an anticyclone on a standard level. The shaded area on a standard level shows a peak, and the other shaded area a mountain.

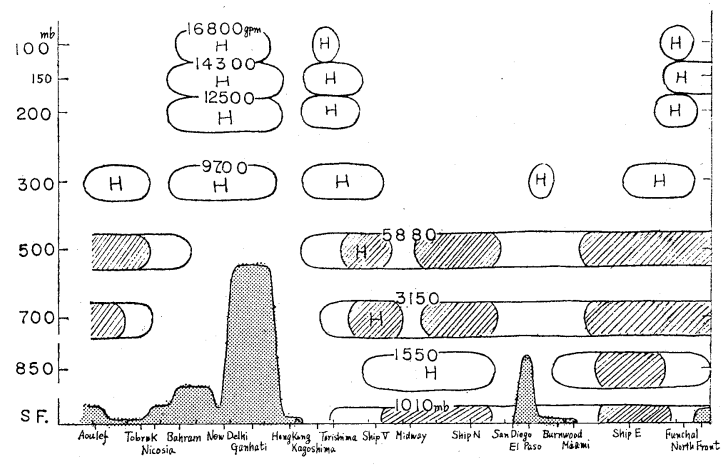

Fig. 6 B. The same as Fig. $6 \mathrm{~A}$, but for August 1959.

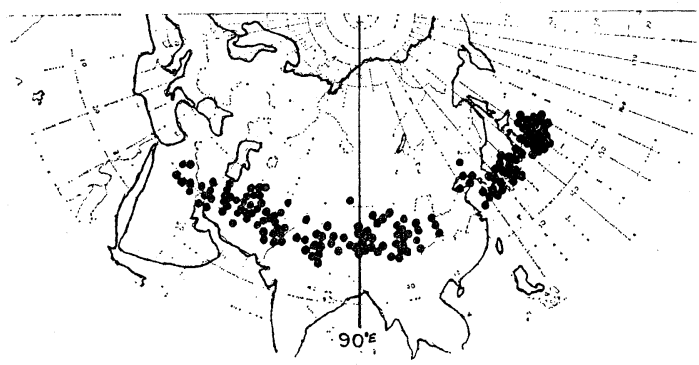

Fig. 7. Distribution of the location of anticyclones on the $100 \mathrm{mb}$ level in August 1964 and 1965. Black circles show daily positions of the centers of anticyclones.

the concentration of center near Japan corresponds to the separate anticyclone on the east coast of the Continent of Eurasia in Fig. 6. In order to see the vertical distribution of isobaric height and temperature over the northwestern Pacific anticyclone in both years, a meridional cross section along $140^{\circ} \mathrm{E}$ is constructed as shown 


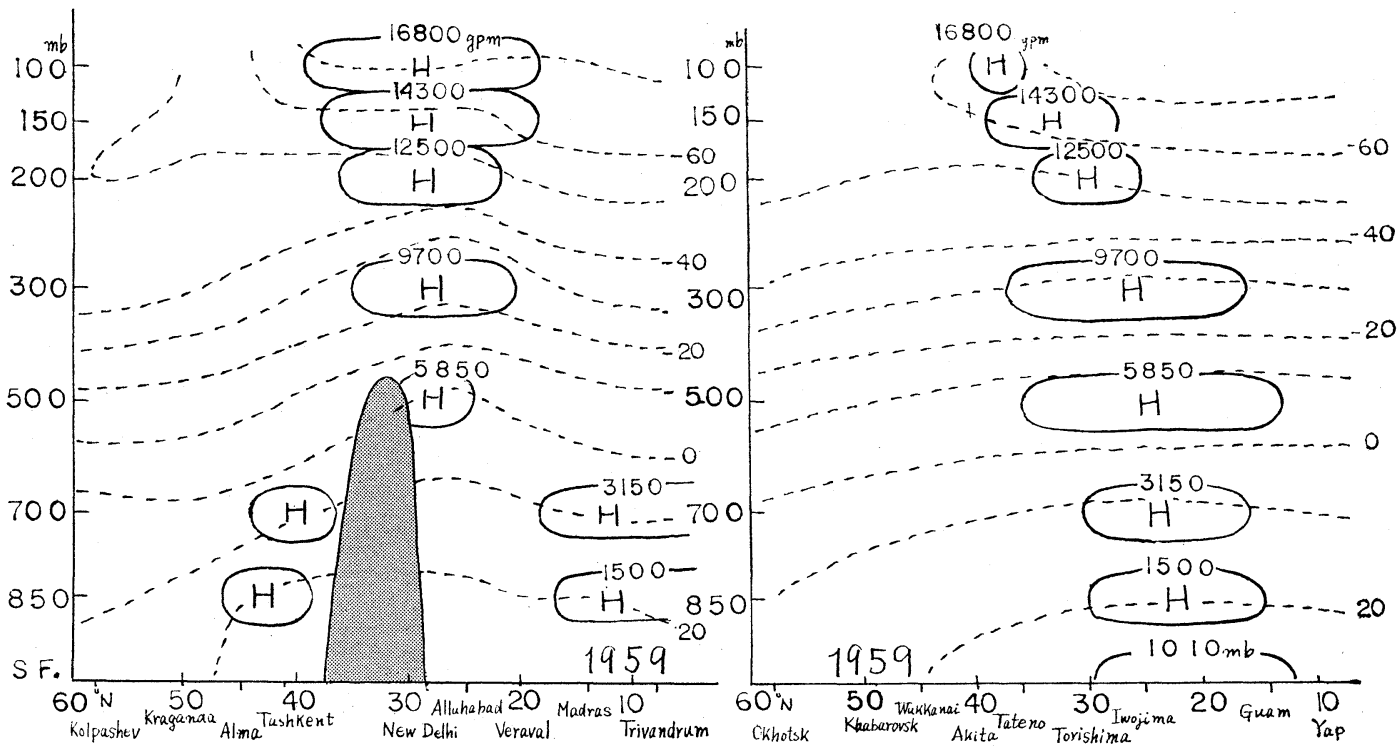

Fig. 8 A. Meridional cross sections of the height and temperature fields along $140^{\circ} \mathrm{E}$ in August 1959 and 1960 respectively. The dashed line indicates the isotherm and the area surrounded by ( $\longrightarrow$ the north-south extent of an anticyclone.

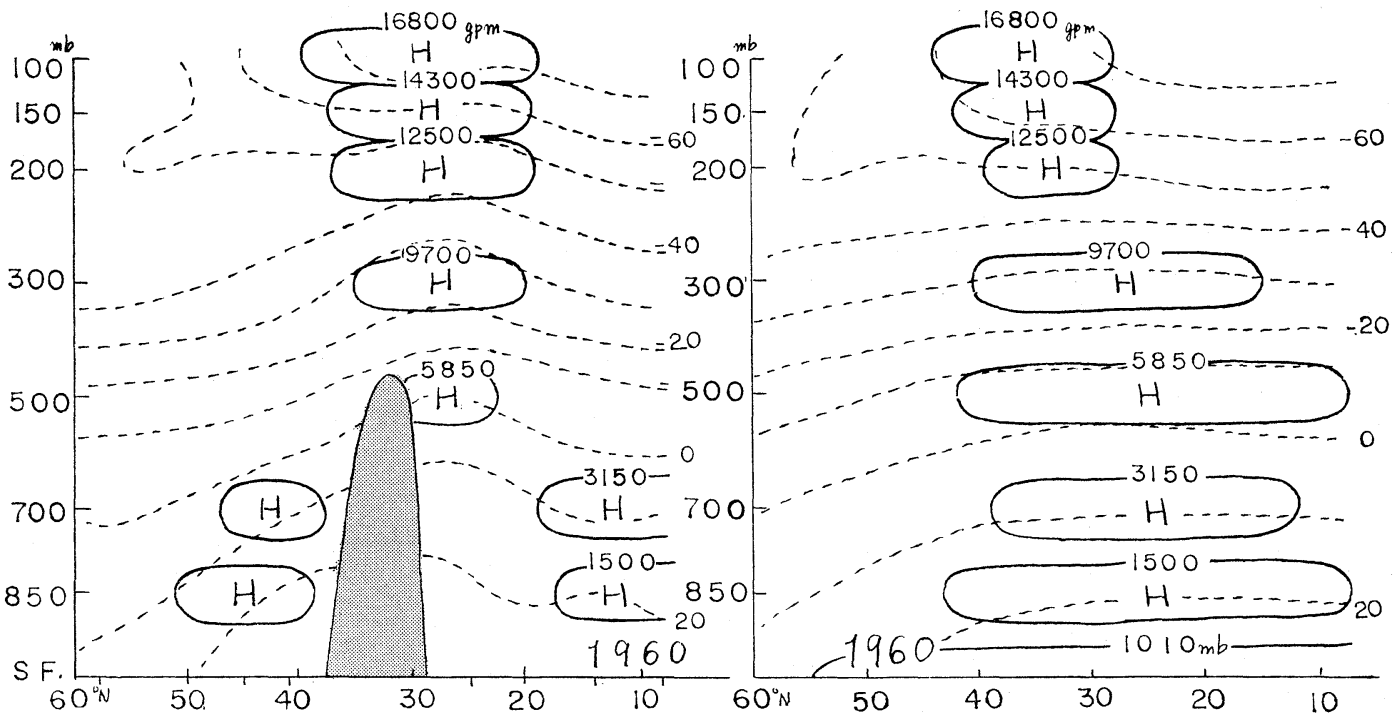

Fig. 8 B. The same as Fig. $8 \mathrm{~A}$, but along $80^{\circ} \mathrm{E}$.

in Fig. $8 \mathrm{~A}$. In this figure, the mark, ( $\square$ ), is the same as Fig. 6. The axis of northwestern Pacific anticyclone tilts toward north in the upper layer from the surface up to the $100 \mathrm{mb}$ level, and the angle of inclination is 10-15 degrees of latitude. In 1959, the year of weak northwestern Pacific anticyclone, the anticyclonic area at each level is narrow as compared with that in the year of 1960 when the anticyclone is strong. In Fig. $8 \mathrm{~B}$, the cross-section along $80^{\circ} \mathrm{E}$ is given. As will be seen in this, the meridional temperature distribution in the southern Asia anticyclone at each level shows a high temperature over the south side of the Tibetan Plateau, and the anticyclonic area surrounded by a certain contour at each level is similar for both years. The figures are omitted, but the similar results are obtained in 1958 and 1961. From the meridional crosssection of the height and temperature over the Atlantic Ocean (Fig. 9 A), it is known that the 


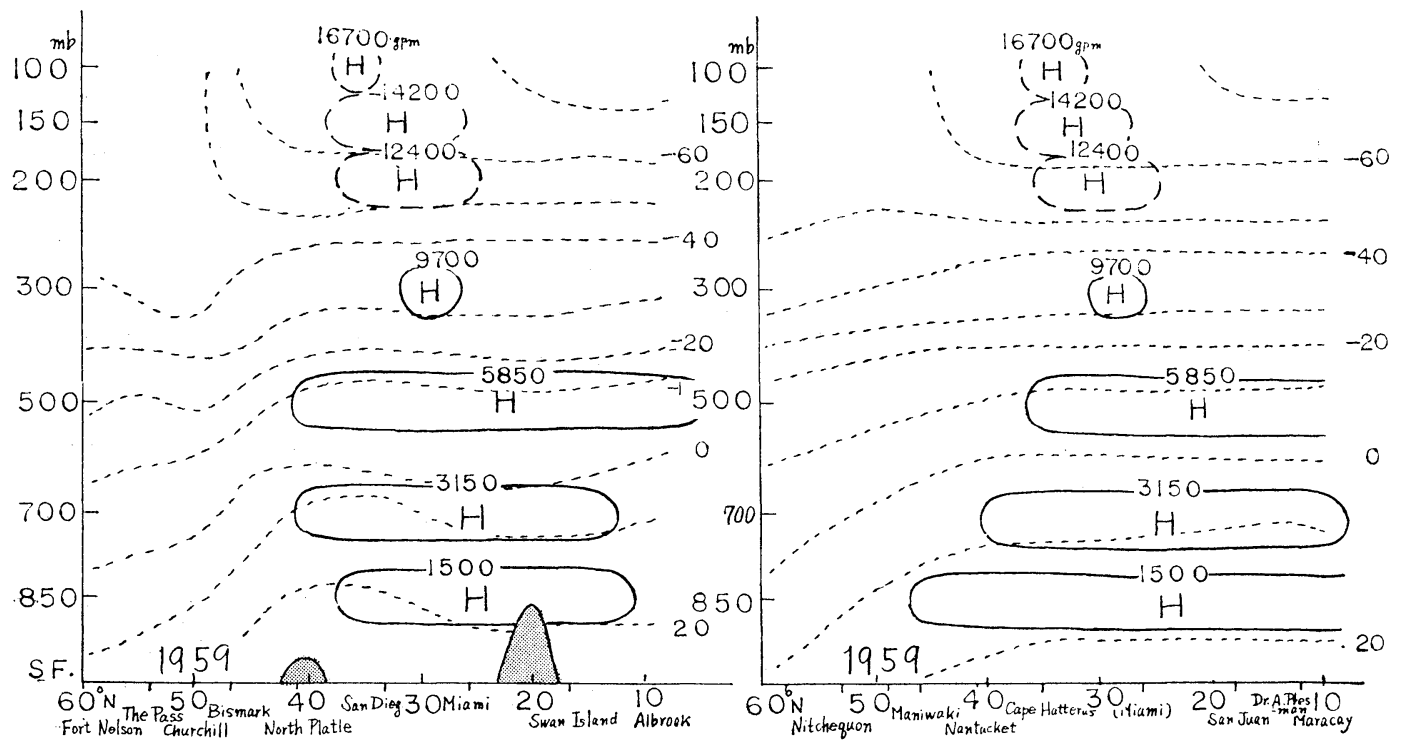

Fig. 9. A. The same as Fig. $8 \mathrm{~A}$, but along $70^{\circ} \mathrm{W}$.

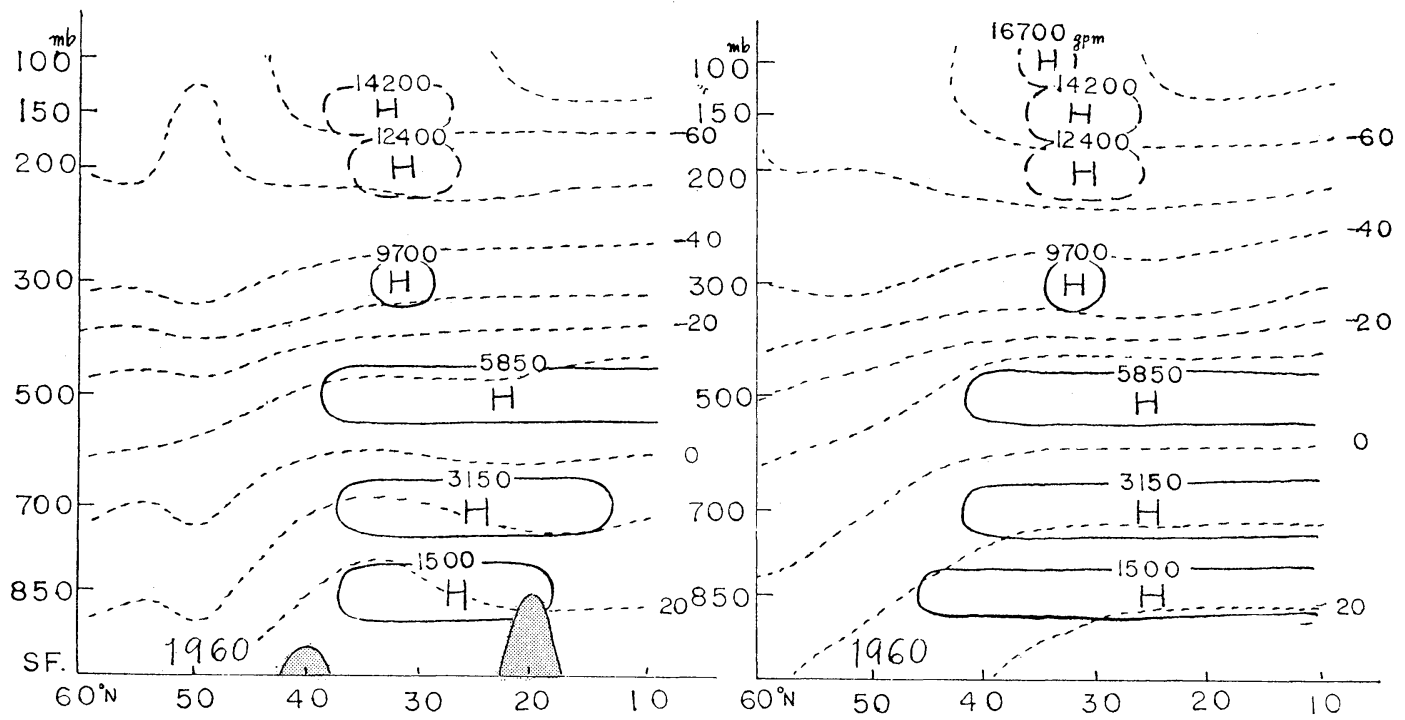

Fig. 9 B. The same as Fig. $8 \mathrm{~A}$, but along $100^{\circ} \mathrm{W}$.

Atlantic anticylone is considerably weak in the upper troposphere as compared with the northwestern Pacific anticyclone, and its axis does not tilt from south toward north. In the meridional cross-section over the North American Continent (Fig. 9 B), such a high temperature as that recognized at each level over the south slope of the Himalayas is not seen over the Rockies. It is grasped that the meridional width of the Atlantic anticyclone shows the same intensity at each level on and lower than $500 \mathrm{mb}$ level in 1959 and 1960, but the anticyclonic area indica- ting a certain height at each level on and over the $200 \mathrm{mb}$ level is not seen in both years. From the vertical cross-sections of the northwestern Pacific and the Atlantic anticyclones, it is seen that both anticyclones at the surface level appear remarkably in the middle and lower troposphere and there is no relation between the strength of the southern Asia anticyclone and that of northwestern Pacific anticyclone as revealed from the study of the meridional and zonal width of both anticyclones. Furthermore, the same fact is seen on the relationship between the North American 
and the Atlantic anticyclone, too. It will be suggested that the southern Asia anticyclone does not couple with the northwestern Pacific anticyclone but the northwestern Pacific anticyclone couples with a separate anticyclone that exists to the east of the southern Asia anticyclone. From the vertical and the meridional temperature distribution in the area of the southern Asia anticyclone and the North American anticyclone, it is supposed that there is a difference in the process of occurrence of both anticyclones, because the southern Asia anticyclone shows a high temperature, but the North American anticyclone does not

\section{The relationship between the subtropical anti- cyclone and the polar low}

It is clear on the mean chart that the centers of action of the hemispheric circulation on the $100 \mathrm{mb}$ level in August is the subtropical anticyclone and the polar low. In order to show the causal relation between the strength of the southern Asia anticyclone as part of the subtropical anticyclone and that of the polar low, the distributions of the $100 \mathrm{mb}$ level height and anomalies in August 1962 and 1964 are given in Fig. 10. In Fig. $10 \mathrm{~A}$ in 1962, the polar low indicated by the contour of $16240 \mathrm{gpm}$ is centered in the neighbourhood of the Greenland, while the southern Asia anticyclone shows the central height of $16800 \mathrm{gpm}$. In 1964 (Fig. $10 \mathrm{~B}$ ), the polar low is split into two and surrounded by $16320 \mathrm{gpm}$ over the Greenland and the northern part of the Chukchin Peninsula, and the positive anomalies with a center of $+120 \mathrm{gpm}$ appears about the north pole. Accordingly, the polar low in 1964 is considerably weaker than that in 1962. The area of the southern Asia anticyclone surrounded by the $16800 \mathrm{gpm}$ contour is narrower in 1964 than that in 1962. Fig. 11 shows the relationship between the intensity of polar low and that of the southern Asia anticyclone surrounded by a certain contour in 1963 and 1965. From this figure, it is seen that the polar low in 1965 develops and the southern Asia anticyclone is weaker than that in 1963, and the same relationship between them as in 1963 is also seen in other years. After all, there seems to exist no relation between the strength of the polar low and that of the southern Asia anticyclone on the $100 \mathrm{mb}$ level.

To investigate the relationship between the

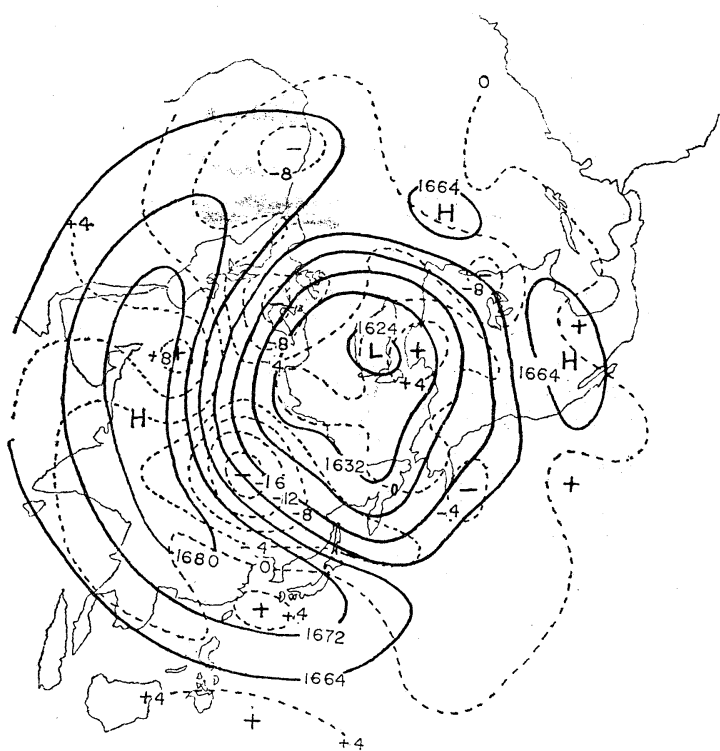

Fig. $10 \mathrm{~A}$. Monthly mean $100 \mathrm{mb}$ height and deviation from normal in August 1962, after Free University of Berlin. The solid line indicates contour, and the dashed line deviation.

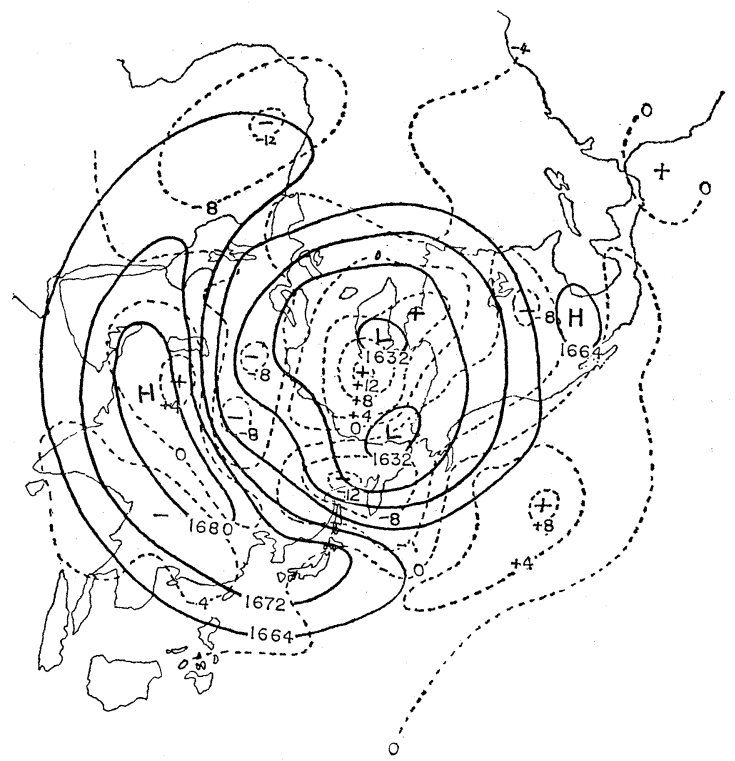

Fig. 10 B. The same as Fig. $10 \mathrm{~A}$, but for August 1964.

subtropical anticyclone and the polar low on the $500 \mathrm{mb}$ level, the distribution of a certain contours and height anomalies of the monthly mean $500 \mathrm{mb}$ maps in 1960 and 1959 is given in Fig. $12 \mathrm{~A}$ and B. From these figures, it is well to 


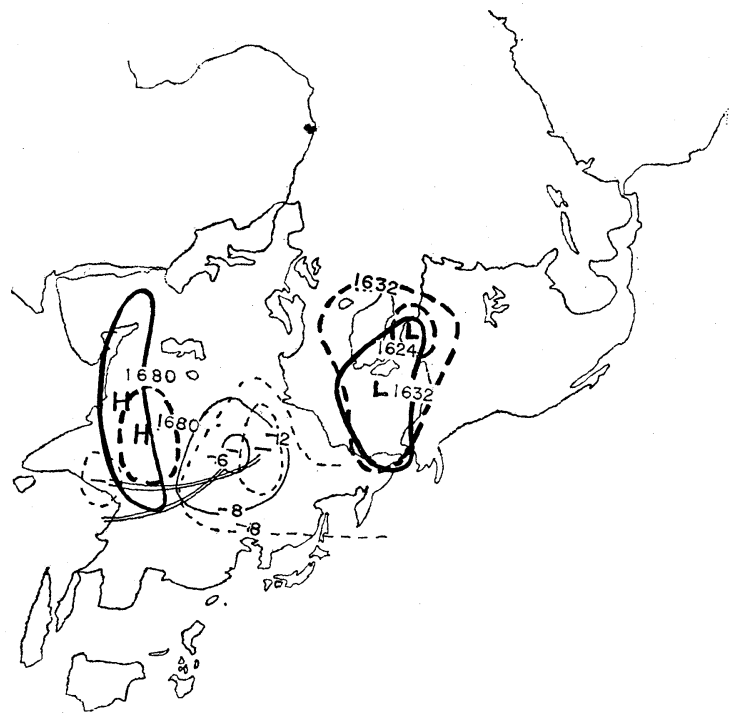

Fig. 11. Relationship between the intensity of the polar low and the extent of the southern Asia anticyclone. The solid line indicates the case for August 1963, the dashed line that for August 1965, and the double line trough.

be seen that the northwestern Pacific anticyclone is weak and covered by negative deviation when the polar low with $-50 \mathrm{gpm}$ deviation develops, whereas the anticyclone is strong when the polar low splits and shows $+100 \mathrm{gpm}$ deviation. Generally, there is the low over about the north pole on the $500 \mathrm{mb}$ and the $100 \mathrm{mb}$ level.

As mentioned above, the intensification of the polar low seems to be associated with the weakening of the subtropical anticyclone on the $500 \mathrm{mb}$ level, but the correspondence between them is indistinct on the $100 \mathrm{mb}$ level. From the relationship between the polar low and the subtropical anticyclone mentioned above, there seems to be no relation between the strength of the southern Asia anticyclone on the $100 \mathrm{mb}$ level and that of the northwestern Pacific anticyclone on the $500 \mathrm{mb}$ level.

5. The relationship between the strength of the northwestern Pacific anticyclone and that of the southern Asia anticyclone

From the study of the vertical structure and the relationship between a polar low and a subtropical anticyclone, no relation was revealed between the intensity of the northwestern Pacific anticyclone and that of the southern Asia anti-

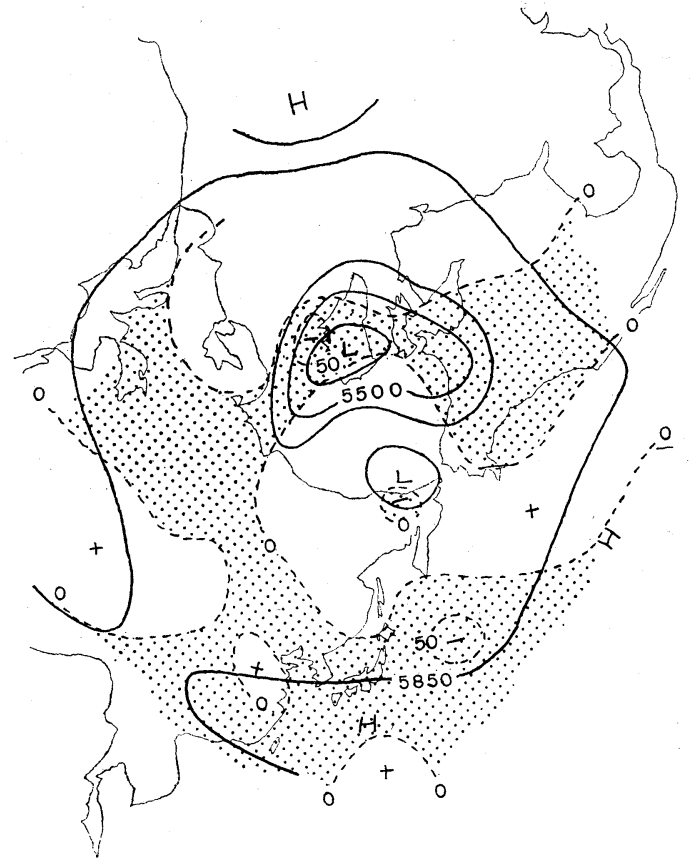

Fig. 12 A. Monthly mean $500 \mathrm{mb}$ height and its deviation from the normal in August 1959, but after Japan Meteorological Agency. The interval is not regular for the convenience of the polar low and the northwestern Pacific anticyclone. The shaded area indicates negative deviation.

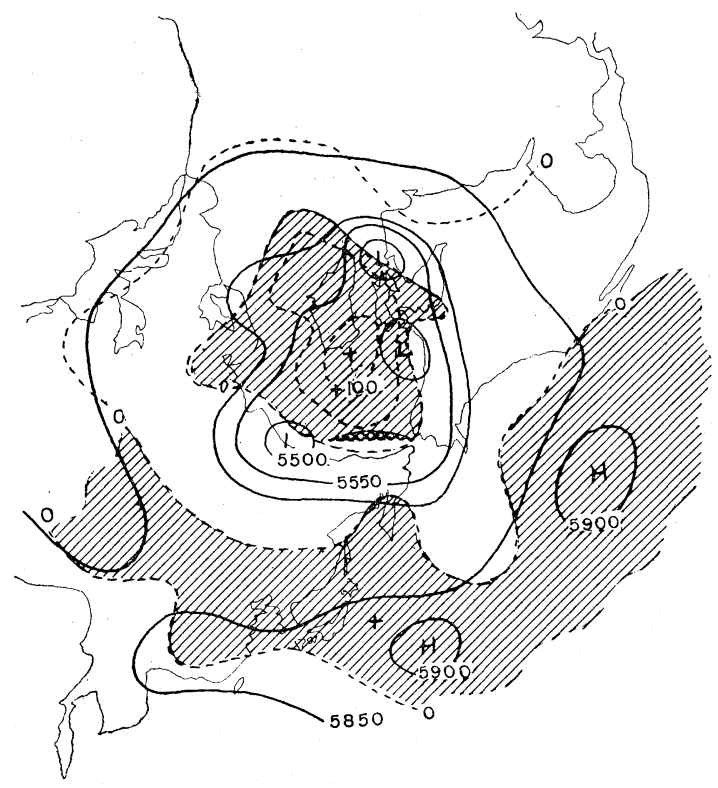

Fig. 12 B. The same as Fig. $12 \mathrm{~A}$, but for August 1960. The shaded area indicates positive deviation. 


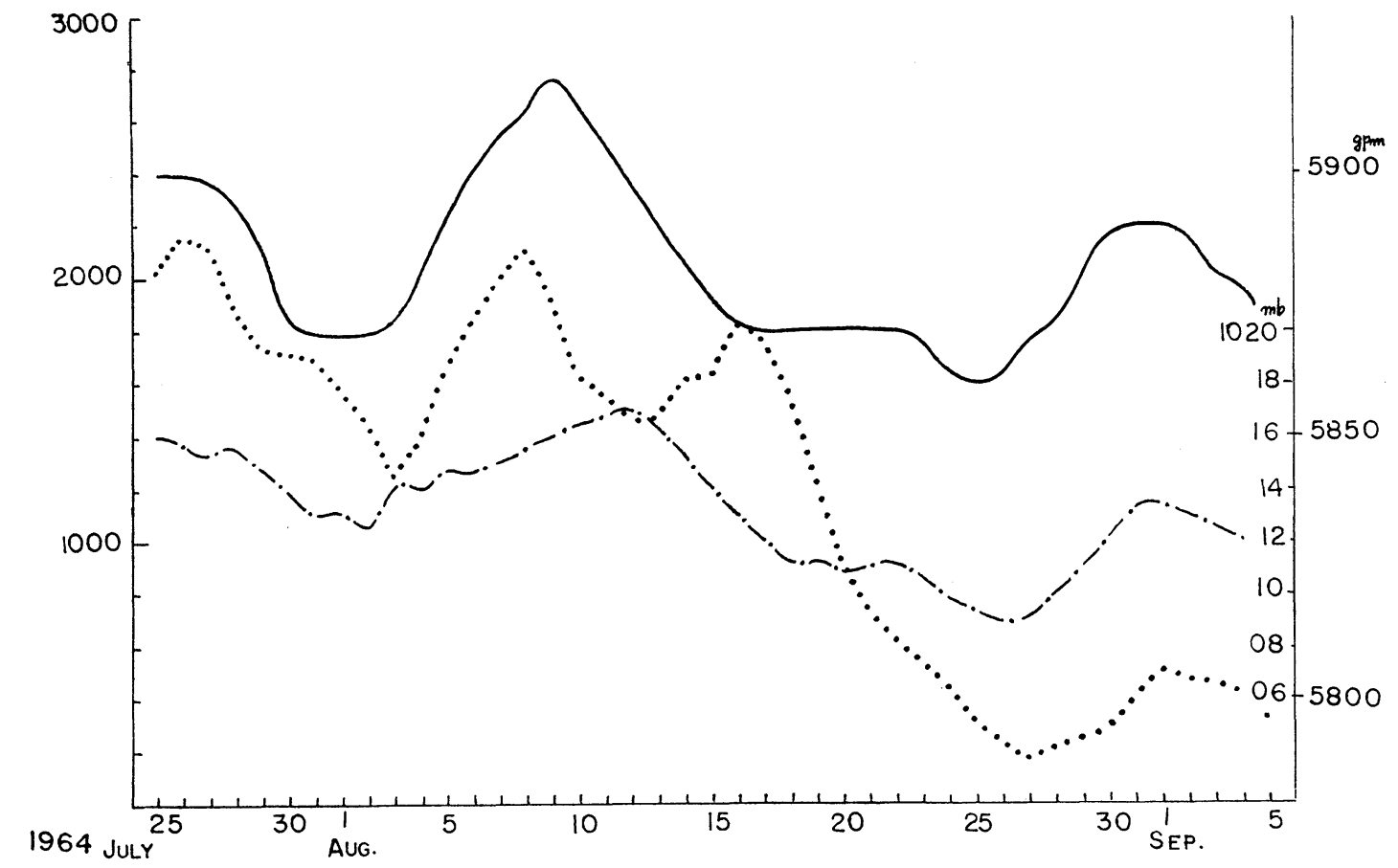

Fig. 13. Time sequence of the intensities of the southern Asia anticyclone on the $100 \mathrm{mb}$ level, the northwestern Pacific anticyclone on the $500 \mathrm{mb}$ level and the Ogasawara anticyclone on the ground surface, from 25.July through 5 Sep. 1964. The dotted line indicates the daily variation of index of intensity of $100 \mathrm{mb}$ anticyclone surrounded by a certain contour, $16800 \mathrm{gpm}$ (the scale of left side), the solid line the daily variation of mean height of the $500 \mathrm{mb}$ height at Torishima, Marcus Is. and Victor, and the dash-dotted line that of the mean surface pressure at the same three stations.

cyclone. In this section, the relationship between both anticyclones is examined by using the daily variation of both anticyclones. In Fig. 13, the variation curves for 1964 are presented as an example. As an index showing the strength of the southern Asia anticyclone on the $100 \mathrm{mb}$ level, an expansion and contraction of the area surrounded by a contour, $16800 \mathrm{gpm}$, or the product of short axis (the latitude width) by long axis (the longitude width) of the elliptic contour is used. The strength of the northwestern Pacific anticyclone at the surface and on the $500 \mathrm{mb}$ level are represented by the mean presuure and height at Torishima $\left(30^{\circ} 29^{\prime} \mathrm{N}, 140^{\circ} 18^{\prime} \mathrm{E}\right)$, Marcus Island $\left(24^{\circ} 18^{\prime} \mathrm{N}, 153^{\circ} 58^{\prime} \mathrm{E}\right)$ and Victor (ship observation point, $34^{\circ} 00^{\prime} \mathrm{N}, 140^{\circ} 58^{\prime} \mathrm{E}$ ) in the northwestern Pacific Ocean. Here the 5-day running mean is taken to show the general tendency of variation. In this figure, it is seen that the daily variation of the northwestern Pacific anticyclone appears nearly simultaneausly at the surface and on the
$500 \mathrm{mb}$ level, but when the southern Asia anticyclone is strong, the surface anticyclone does not always develop. Especially, the southern Asia anticyclone suddenly weakens at the third decade of August, but such an indication is not seen in the northwestern Pacific anticyclone.

\section{Thermal structure of the subtropical anticyclone}

In the zonal distribution of thickness in the upper troposphere along $30^{\circ} \mathrm{N}$ (Fig. 14), it is found that the layers of $300-500 \mathrm{mb}, 200-300 \mathrm{mb}$ and $100-200 \mathrm{mb}$ are warm over the Continent of Eurasia, and cold over the Pacific Ocean. High temperature is not seen over the North American Continent, and low temperature over the Atlantic Ocean is not clear. Still, the remarkable high temperature at the layer of $100-200 \mathrm{mb}$ over the northwestern Pacific bases on the strong cold low on the $200 \mathrm{mb}$ level over the sea of the west of the North American Continent (the same as in 1957), so high temperature over the north- 


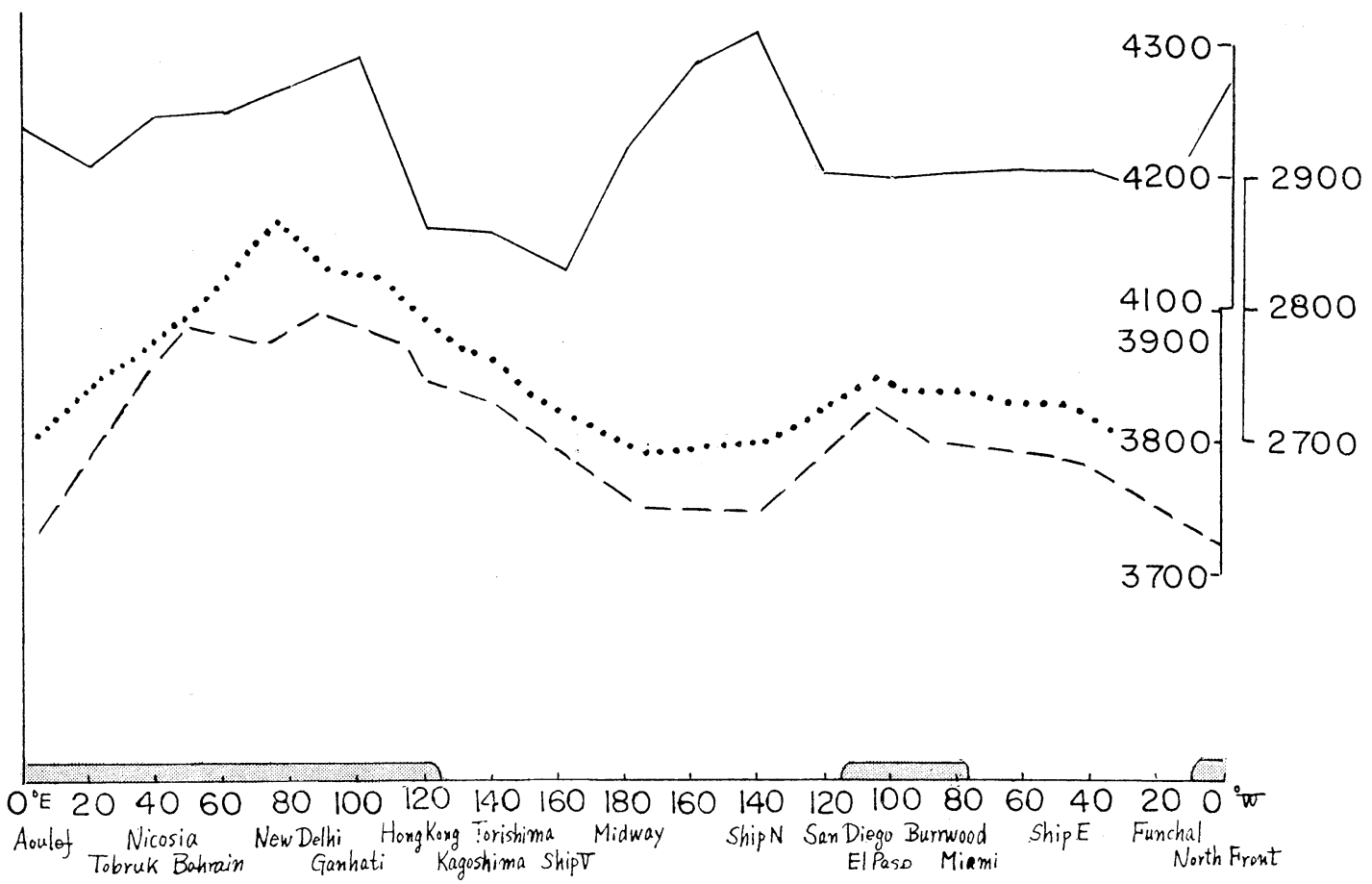

Fig. 14. Zonal corss section of thickness along $30^{\circ} \mathrm{N}$ latitude in August 1958. The solid line indicates thickness between $100 \mathrm{mb}$ and $200 \mathrm{mb}$ level, the dotted line $200-300 \mathrm{mb}$, and the dashed line 300-500 mb.

western Pacific Ocean differs from the situation of the high temperature over the Tibetan Plateau. If it is possible to suppose that the southern Asia anticyclone is produced by the rise of isobaric surface due to the heating of the Tibetan Plateau, the action is the strongest close under the $100 \mathrm{mb}$ level where the anticyclone appears most remarkably. On the other hand, the North American anticyclone indicates scarcely a high temperature. This difference may be attributed to the different structure and trend of the Himalayas and the Rockies. The fact that the southern Asia anticyclone shows a high temperature while the northwestern Pacific anticyclone indicates a low temperature as manifested by the thickness distribution in the middle latitudes in the upper troposphere, points to the difference of the two anticyclones in the mechanism of the production.

\section{Conclusions}

In this paper, the vertical structure of the subtropical anticyclone in August is studied. The results are summarized as follows:

1. The subtropical anticyclones have a similar vertical structure in the lower half of the troposphere in the Pacific Ocean and the Atlantic Ocean.

2. From $300 \mathrm{mb}$ through $100 \mathrm{mb}$ levels there is little relation between the strength of the northwestern Pacific anticyclone at the surface level and that of the southern Asia anticyclone on the $100 \mathrm{mb}$ level; between the strength of the Atlantic anticyclone at the surface level and that of the North America anticyclone on the $100 \mathrm{mb}$ level.

3. It is difficult to consider that the northwestern Pacific anticyclone at the surface level is vertically connected with the southern Asia anticyclone over the Tibetan Plateau.

4. It is considered that the upper anticyclone, which has been considered as the extension of the northwestern Pacific anticyclone at the surface level, may be found as a separate anticyclone or an anticyclonic cell appearing over the eastern part of the southern Asia anticyclone.

5. The strength and the high temperature of southern Asia anticyclone may be influenced by the topographical effect of the Himalayas. The temperature observed in the southern Asia anti- 
cyclone is higher than that of the North American anticyclone. The latter is weaker in its intensity than the former.

\section{Acknowledgments}

The writer wishes to express his appreciation to Professor R. Yamamoto of Kyoto University, who lent him many stratospheric charts. Also the writer would like to thank Dr. K. Suda of the Meteorological Research Institute, Japan Meteorological Agency, who revised the original manuscript.

\section{References}

Institute für Meteorologie und Geophysik der Freien Universität, Berlin, 1962: Daily. and monthly Northern Hemisphere 50 and $100 \mathrm{mb}$ synoptic weather maps. Meteor. Abhandl., Band XXV, XXXIII, Heft 3.

, 1963: Daily and monthly Northern Hemisphere 50 and $100 \mathrm{mb}$ synoptic weather maps. Meteor. Abhandl., Band XXXIX, XXXVII, Heft 3. Hemisphere 50 and $100 \mathrm{mb}$ synoptic weather maps. Meteor. Abhandl., Band XLVIII, XLVI, Heft 3.
1965: Daily and monthly Northern Hemisphere 50 and $100 \mathrm{mb}$ synoptic weather maps. Meteor. Abhandl., Band LVII, LV, Heft 3.

Kochanski, A., 1955: Cross section of the mean zonal flow and temperature along $80^{\circ} \mathrm{W}$. J. Meteor., 12, 95-106.

Neyama, Y., 1965: A relationship between the $100 \mathrm{mb}$ anticyclone over Asia and the Ogasawara anticyclone. J. meteor. Soc. Japan, 43, 401-406.

, 1966: A relationship between the stratospheric circulation and the seasonal transition. $J$. meteor. Soc. Japan, 44, 159-166.

, 1967: On a seasonal decay of the Ogasawara anticyclone. J. meteor. Soc. Japan, 45, 353-361.

Dao Shih-yen and Chu Fu-kang, 1965: Variations of the $100 \mathrm{mb}$ flow pattern over southern Asia in summer and its relation to advance and retreat of the west Pacific subtropical anticyclone. (in Chinese) Acta Meteorologica Sinica, 34, 385-396.

U.S. Air Force Survey Geophysics, 1962: Atlas of monthly mean stratospheric charts, 1955-1959, Part 1 and 2.

U.S. Weather Bureau: Monthly climatu data for the world and daily data.

Yoshino, M., 1967: Atmospheric circulation over the Northeast Pacific in summer. Meteor. Rundschau, 20, 45-52.

\section{亜熱帯高気压の形態}

\section{根 山 芳 晴 \\ 広島地方気象台}

亜熱帯高気圧の形態を研究するため, 同高気圧が最も顕著に現われる8月の平均場を対流圈と成層圈を含めて解析 し次のことがわかつた。上層の各等圧面間に和けるシックネスの $30^{\circ} \mathrm{N}$ に沿ら分布によると，南部アジア高気圧内 は $500 \mathrm{mb}$ 面より高い層内で高温になつて扣り，一方北西太平洋高気圧内は低温になつている。また北米大陸上の 高気圧は南部アジア高気压に較べて気温が低く大西洋高気圧内の低温ははつきりしない。これら両大陸上の高気圧 は強さが異つており，それは高温をもたらすと考省られるチベット高原の走向や構造がロッキー山脈と異ることに 起因しているか子知れない。500mb 面での北西太平洋高気圧の強弱は極低気圧の強弱対応しているが，100mb 面 での極低気圧に対しては南部アジア高気圧の強弱は対応していない。さらに $30^{\circ} \mathrm{N}$ に沿う垂直断面図上でみると、 南部アジア高気圧の強弱は北西太平洋高気圧の強弱に対応していない。これらの事実から地上の北西太平洋高気圧 は南部アジア上の高気压に連らなつた垂直軸を持つているとは考え難い。その中心は上層に向つて西に傾き, $100 \mathrm{mb}$ 面ではアジア大陸東海上にできる別の高気圧性セルに連らなる構造をもつていると考えられる。地上から中部対流 圏に卓越する太西洋高気圧と北米上の $100 \mathrm{mb}$ 高気圧との間の垂直方向の対応性ははつきりしない。また $300 \mathrm{mb}$ 面 から $100 \mathrm{mb}$ 面の間に顕著に現わ玌る南部アジア高気圧に対して北米高気圧はその強さがかなり弱いよらである。 